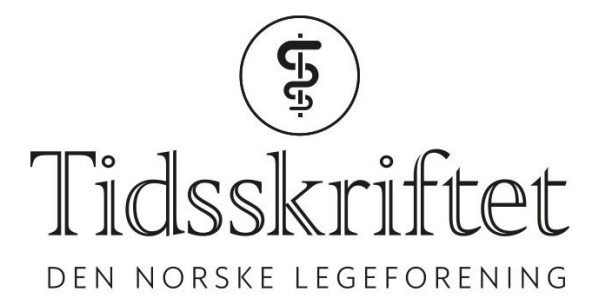

\title{
Netthinneblødninger og filleristede spedbarn
}

DEBATT

OLAV H. HAUGEN

E-post: olav.haugen@helse-bergen.no

Olav H. Haugen er seksjonsoverlege ved Seksjon for barneoftalmologi og strabisme, Øyeavdelingen, Haukeland universitetssjukehus, og professor ved Klinisk institutt 1, Universitetet i Bergen. Forfatteren har fylt ut ICMJE-skjemaet og oppgir følgende interessekonflikter: Han har vært medisinsk sakkyndig i noen saker om vurdering av netthinneblødninger ved mistenkt hodeskade hos barn.

Kritikere av dagens diagnostikk av «filleristing» av spedbarn uttaler seg på sviktende grunnlag om komplekse vurderinger som ligger utenfor deres eget fagfelt.

I Tidsskriftet går det en debatt om «filleristing» av barn (abusive head trauma, AHT) (1-4). I to innlegg har Knut Wester $(1,3)$ etterlyst vitenskapelig holdbar dokumentasjon for at voldsom risting alene kan forårsake fatal hjerneskade. Han har fått støtte av Niels Lynøe og Anders Eriksson (4) som har påpekt store metodiske svakheter i litteraturen. Wester viser til at sentrale artikler om netthinneblødninger ved «påført hodeskade» baserer diagnosesettingen på tverrfaglige diagnoseteam, ikke på dokumentert «filleristing» (3). Høy forekomst av netthinneblødninger blir ifølge ham en selvoppfyllende profeti - eller en sirkelargumentasjon - fordi netthinneblødninger inngår i diagnosesettingen. Lynøe og Eriksson påpeker at bedømmingen av netthinneblødninger generelt er upålitelig og at fødselsrelaterte netthinneblødninger må has in mente (4). På bakgrunn av mange års erfaring som øyelege for barn og med basis i den oftalmologiske litteraturen vil jeg få kommentere deler av debatten som omhandler netthinneblødninger.

\section{Sirkelargumentasjon}

To sentrale referanser gjør spesifikt rede for diagnostikk av "påførte hodeskader» uavhengig av øyefunn. En amerikansk studie omfattet 110 barn $<15$ måneder innlagt for mistenkt påført hodeskade (5). Wester henviser til denne artikkelen som et eksempel på studier der diagnose kun er basert på tverrfaglige team. En viktig detalj er imidlertid at barna ble vurdert etter en algoritme som ikke inkluderte øyefunn. De ble deretter undersøkt av øyelege, og netthinneblødninger ble dokumentert. På grunnlag av en rekke karakteristika ved netthinneblødningene (størrelse, beliggenhet/sjikt i retina og utbredelse) laget man en skår (o-6) for hvert øye. En skår på $\geq_{5}$ forekom i 40 \% ved påførte hodeskader og i 5 \% ved ulykker. En skår på $\geq 9$ ble kun sett ved påførte hodeskader. Siden øyefunn ikke inngikk i diagnostikken, faller poenget om sirkelargumentasjon bort.

Den andre studien var en prospektiv studie på spedbarn (6) der kun tilfeller av bevitnet eller innrømmet påført hodeskade (45 barn) samt bevitnet ulykke (39 barn) ble inkludert. 
Forekomst og karakteristika av netthinneblødningene (antall, utbredelse, størrelse og sjikt i retina) viste en signifikant forskjell mellom påført hodeskade og bevitnet ulykke, med en spesifisitet på o,97. Lynøe og Eriksson skriver at en så høy spesifisitet er suspekt, og hevder at også forfatteren har innrømmet dette (7). Den som leser forfatterens tilsvar, vil se at Lynøe og Eriksson forvrenger meningsinnholdet, at forfatteren fastholder sine resultater og at de per i dag har samlet 281 bevitnede tilfeller (påførte hodeskader og ulykker), med tilsvarende resultater som de opprinnelige 84 tilfellene.

\section{Bedømming av netthinneblødninger}

Lynøe og Eriksson siterer en studie (8) som angivelig viser at presisjonen ved å bedømme om et bilde av netthinneblødninger stammet fra et mishandlet barn eller en ulykke, var «obetydligt bättre än slumpen». Forskningsspørsmålet i denne studien var imidlertid om det på grunnlag av netthinnebilder var mulig å avgjøre i hvilket lag/sjikt av retina blødningene ligger. Resultatene viste at det var «brukbar» enighet (fair agreement) mellom unders $\emptyset$ kerne. Dette er imidlertid bare ett av mange karakteristika. En grundig vurdering av netthinneblødninger ved mistanke om påført hodeskade omfatter mange andre forhold: ett eller begge øyne, antall, størrelse og utbredelse i netthinnen. I en liknende studie så man på inter- og intra-rater enighet/samstemmighet når det gjaldt antall og utbredelse/lokalisasjon i netthinnen (9). Her fant forfatterne svært stor grad av enighet (substantial to perfect agreement). Lynøe og Erikssons har misforstått problemstillingen $\mathrm{i}$ den siterte studien, og deres generelle påstand om upåliteligheten ved bedømming av netthinneblødningene ved mishandling er derfor bygget på sviktende argumentasjon.

\section{Netthinneblødninger etter fødsel}

Lynøe og Eriksson skriver at netthinneblødninger etter fødsel kan være en aktuell differensialdiagnose ved mistenkt påført hodeskade. Litteraturen viser at slike netthinneblødninger i hovedsak er forsvunnet etter 14 dager. Eksempelvis viste en oversiktsartikkel som omfatter nesten 1800 barn, at $83 \%$ av blødningene var forsvunnet etter 10 dager og at samtlige var forsvunnet etter 58 dager (10).

Verken Wester eller Lynøe og Eriksson har satt seg godt nok inn i den eksisterende oftalmologiske litteraturen, som på et svært vanskelig forskningsfelt dokumenterer at tallrike og utbredte netthinneblødninger gir en svært høy spesifisitet for påført hodeskade. I debatten bør man ha respekt for hverandres ulike fagfelt og faglige integritet og være omhyggelig med å sitere litteraturen korrekt.

\section{LITTERATUR:}

1. Wester K. Har et «filleristet spedbarn» alltid vært filleristet? Tidsskr Nor Legeforen 2018; 138. doi: 10.4045/tidsskr.18.0583. [PubMed][CrossRef]

2. Stray-Pedersen A, Møller C, de Lange C et al. Legers rolle ved mistanke om alvorlig barnemishandling. Tidsskr Nor Legeforen 2018; 138. doi:10.4045/tidsskr.18.0922. [PubMed][CrossRef]

3. Wester K. Grunnleggende uenighet om filleristing. Tidsskr Nor Legeforen 2019; 139. doi: 10.4045/tidsskr.19.0oo1. [PubMed][CrossRef]

4. Lynøe N, Eriksson A. Skakvåld mot spädbarn - läkarens roll måste särskiljas från rättsväsendets roll. Tidsskr Nor Legeforen 2019; 139. doi:10.4045/tidsskr.19.0035. [PubMed][CrossRef]

5. Binenbaum G, Mirza-George N, Christian CW et al. Odds of abuse associated with retinal hemorrhages in children suspected of child abuse. J AAPOS 2009; 13: 268-72. [PubMed][CrossRef]

6. Vinchon M, de Foort-Dhellemmes S, Desurmont M et al. Confessed abuse versus witnessed accidents in infants: comparison of clinical, radiological, and ophthalmological data in corroborated cases. Childs Nerv Syst 2010; 26: 637-45. [PubMed][CrossRef]

7. Vinchon M. Response to Lynøe: questions about isolated trauma shaking and confessions. Childs 
Nerv Syst 2017; 33:1423-4. [PubMed][CrossRef]

8. Mulvihill AO, Jones P, Tandon A et al. An inter-observer and intra-observer study of a classification of RetCam images of retinal haemorrhages in children. Br J Ophthalmol 2011; 95: 99-104.

[PubMed][CrossRef]

9. Fleck BW, Tandon A, Jones PA et al. An interrater reliability study of a new 'zonal' classification for reporting the location of retinal haemorrhages in childhood for clinical, legal and research purposes. Br J Ophthalmol 2010; 94: 886-9o. [PubMed][CrossRef]

10. Watts P, Maguire S, Kwok T et al. Newborn retinal hemorrhages: a systematic review. J AAPOS 2013; 17: 70-8. [PubMed][CrossRef]

Publisert: 6. mai 2019. Tidsskr Nor Legeforen. DOI:10.4045/tidsskr.19.0196

Mottatt 7.3.2019, første revisjon innsendt 15.3.2019, godkjent 19.3.2019.

(C) Tidsskrift for Den norske legeforening 2020. Lastet ned fra tidsskriftet.no 